\title{
On the Evolution of Trust, Distrust, and Formal Coordination and Control in Interorganizational Relationships: Towards an Integrative Framework
}

\author{
Paul W.L. Vlaar, Frans A.J. Van den Bosch and Henk W. Volberda
}

\begin{tabular}{|l|l|}
\hline \multicolumn{2}{|l|}{ ERIM REPORT SERIES RESEARCH IN MANAGEMENT } \\
\hline ERIM Report Series reference number & ERS-2006-035-STR \\
\hline Publication & July 2006 \\
\hline Number of pages & 31 \\
\hline Persistent paper URL & \\
\hline Email address corresponding author & pvlaar@rsm.nl \\
\hline Address & Erasmus Research Institute of Management (ERIM) \\
& RSM Erasmus University / Erasmus School of Economics \\
& Erasmus Universiteit Rotterdam \\
& P.O.Box 1738 \\
& 3000 DR Rotterdam, The Netherlands \\
& Phone: $\quad+31104081182$ \\
& Fax: $\quad+31104089640$ \\
& Email: info@erim.eur.nl \\
& Internet: $\quad$ www.erim.eur.nl \\
\hline
\end{tabular}

Bibliographic data and classifications of all the ERIM reports are also available on the ERIM website: www.erim.eur.nl 


\section{ERASMUS RESEARCH INSTITUTE OF MANAGEMENT}

\section{REPORT SERIES \\ RESEARCH IN MANAGEMENT}

\begin{tabular}{|c|c|}
\hline \multicolumn{2}{|c|}{ ABSTRACT AND KEYWORDS } \\
\hline Abstract & $\begin{array}{l}\text { In this article, we discuss the evolution of trust, distrust, and formal coordination and control in } \\
\text { interorganizational relationships. We suggest that the degrees to which managers trust and } \\
\text { distrust their partners during initial stages of cooperation leave strong imprints on the } \\
\text { development of these relationships in later stages of collaboration. This derives from the impact } \\
\text { of trust and distrust on: (1) formal coordination and control; (2) interorganizational performance; } \\
\text { and (3) the interpretations that managers attribute to the behavior of their partners. Collectively, } \\
\text { our arguments give rise to a conceptual framework, which indicates that there is a high } \\
\text { propensity for interorganizational relationships to develop along vicious or virtuous cycles. By } \\
\text { integrating and reconciling previous work on the trust-control nexus, and by emphasizing the } \\
\text { dynamics associated with it, the article contributes to a more comprehensive and refined } \\
\text { understanding of the evolution of interorganizational cooperation. }\end{array}$ \\
\hline Free Keywords & Trust, Distrust, Formal Coordination, Formal Control, Evolution, Interorganizational Relationship \\
\hline Availability & $\begin{array}{l}\text { The ERIM Report Series is distributed through the following platforms: } \\
\text { Academic Repository at Erasmus University (DEAR), DEAR ERIM Series Portal } \\
\text { Social Science Research Network (SSRN), SSRN ERIM Series Webpage } \\
\text { Research Papers in Economics (REPEC), REPEC ERIM Series Webpage }\end{array}$ \\
\hline Classifications & $\begin{array}{l}\text { The electronic versions of the papers in the ERIM report Series contain bibliographic metadata } \\
\text { by the following classification systems: } \\
\text { Library of Congress Classification, (LCC) LCC Webpage } \\
\text { Journal of Economic Literature, (JEL), JEL Webpage } \\
\text { ACM Computing Classification System CCS Webpage } \\
\text { Inspec Classification scheme (ICS), ICS Webpage }\end{array}$ \\
\hline
\end{tabular}




\title{
On the Evolution of Trust, Distrust, and Formal Coordination and Control in Interorganizational Relationships: Towards an Integrative Framework
}

\author{
Paul W.L. Vlaar \\ Frans A.J. Van Den Bosch \\ Henk W. Volberda
}

Department of Strategic Management and Business Environment RSM Erasmus University

Erasmus University Rotterdam

P.O. Box 1738, 3000 DR Rotterdam, The Netherlands

Phone: +31 10 4082005/9613; Fax: +31 104089013

E-mail: pvlaar@,rsm.nl

$\underline{\text { www.strategyaterasmus.nl }}$

\begin{tabular}{|c|}
\hline Final version March 2006 \\
Paper accepted for publication in : \\
Group \& Organization Management \\
\hline
\end{tabular}




\title{
On the Evolution of Trust, Distrust, and Formal Coordination and Control in Interorganizational Relationships: Towards an Integrative Framework
}

\begin{abstract}
In this article, we discuss the evolution of trust, distrust, and formal coordination and control in interorganizational relationships. We suggest that the degrees to which managers trust and distrust their partners during initial stages of cooperation leave strong imprints on the development of these relationships in later stages of collaboration. This derives from the impact of trust and distrust on: (1) formal coordination and control; (2) interorganizational performance; and (3) the interpretations that managers attribute to the behavior of their partners. Collectively, our arguments give rise to a conceptual framework, which indicates that there is a high propensity for interorganizational relationships to develop along vicious or virtuous cycles. By integrating and reconciling previous work on the trust-control nexus, and by emphasizing the dynamics associated with it, the article contributes to a more comprehensive and refined understanding of the evolution of interorganizational cooperation.
\end{abstract}

KEY WORDS: Trust, Distrust, Formal Coordination, Formal Control, Evolution, Interorganizational Relationship 


\section{INTRODUCTION}

Interorganizational governance issues have attracted growing attention from academics and practitioners due to the increasing number of alliances, outsourcing relationships and other forms of inter-firm exchange, and the governance issues associated with these relationships (see Gulati and Singh, 1998; Kale, Dyer, and Singh, 2002; McEvily, Perrone, and Zaheer, 2003a). The corresponding literature distinguishes several governance forms by which cooperating parties may govern these relationships, primarily emphasizing trust and formalization (BijlsmaFrankema and Koopman, 2004; García-Canal, Valdés-Llaneza, and Ariño, 2003; Luo, 2002; Poppo and Zenger, 2002). In line with this, different theoretical perspectives on the significance of trust and formalization, and on the interplay between them, have emerged. In particular, contributions have emphasized: (1) that trust and formalization may act as substitutes (e.g. Das and Teng, 2001; Dyer and Singh, 1998; Gulati, 1995; Inkpen and Currall, 2004; Zaheer and Venkatraman, 1995); (2) that they may function as complements (e.g. Deakin and Wilkinson, 1998; Mayer and Argyres, 2004; Poppo and Zenger, 2002; Sitkin, 1995; Zucker, 1986); (3) that they have a variety of performance effects (e.g. Luo, 2002; Kern, 1998; Mayer and Argyres, 2004; Sydow and Windeler, 2003); and, (4) that they may develop along self-reinforcing cycles (e.g. Ghoshal and Moran, 1996; Inkpen and Curall, 2004; Macaulay, 1963; Zand, 1972).

Despite these contributions, the relationships between trust and formalization remain far from clear (Maguire, Phillips, and Hardy, 2001; Sydow and Windeler, 2003), and much theoretical input is still needed to understand how they work as governance mechanisms (Bachmann, 2001). In particular, the role of trust and formalization in the process of relationship development and their evolution during cooperative endeavors deserve more attention (De Wever, Martens, and Vandenbempt, 2005; Inkpen and Curall, 2004). In line with this, calls have been issued for more 
integrative approaches towards theory development and more dynamic representations of the trust-control nexus (Bijlsma-Frankema and Costa, 2005; Bijlsma-Frankema and Koopman, 2004). In this article, we undertake a first step in this direction by addressing the following research question: How do trust and formalization evolve in interorganizational relationships?

To investigate this question, we distinguish trust from distrust, and formal coordination from formal control. We then introduce a conceptual framework in which we incorporate two other variables, being interorganizational performance and managers' interpretations of partner behavior. This framework contributes to the literature in two ways. First, it transcends prior work on interorganizational governance issues through the systematic integration of a range of contributions on the roles of trust and formalization in interorganizational relationships and on the interrelationships between them (as advocated by Bachmann, 2004; Bachmann, Knights, and Sydow, 2001; Bijlsma-Frankema and Koopman, 2004; McEvily et al., 2003a). Second, by reconciling apparently inconsistent arguments and empirical evidence on the trust-control nexus (Bachmann et al., 2001; Bijlsma-Frankema and Costa, 2005), we are able to describe how interorganizational governance may evolve, something which has received little attention in the literature thus far (Inkpen and Currall, 2004; Klein Woolthuis, Hillebrand, and Nooteboom, 2005). We explain why trust and distrust during initial stages of cooperation leave strong imprints on the development of collaborative relationships in later stages of development by elucidating their impact on formal coordination and control, interorganizational performance, and the interpretations that managers attribute to the behavior of their partners.

The article proceeds along the following lines. We start by defining the main constructs in our study. Subsequently, we introduce our conceptual framework, and we explain how trust, distrust, 
and formal coordination and control may evolve during collaborative relationships. We do so by consecutively discussing the effects of trust and distrust on formal coordination and control, on interorganizational performance, and on managers' interpretations of partner behavior. We conclude with a brief summary, the theoretical and practical implications of our study, and opportunities for further research.

\section{DEFINING THE MAIN CONSTRUCTS}

In this paragraph, we define the major constructs in our study, starting with trust. Rousseau et al. (1998, p. 395) define trust as "a psychological state comprising the intention to accept vulnerability based upon positive expectations of the intentions or behavior of another". This definition implies that trust involves choice (Luhmann, 1988), and the existence of risk (Mayer, Davis, and Schoorman, 1995). Nooteboom explicitly addresses these points in his definition of trust, stating that it "entails that one does not expect to be harmed by a partner even though she has both the opportunity and the incentive to be opportunistic" (1999, p. 203). His definition indicates that trust consists of a subjective state of positive expectations (Das and Teng, 2001), and that the partner and its behavior are the objects of trust (Inkpen and Currall, 2004). Accordingly, we follow Mayer et al. (1995, p. 712) in defining trust as "the willingness of a party to be vulnerable to the actions of another party based on the expectation that the other will perform a particular action important to the trustor, irrespective of the ability to monitor or control that other party". Trust not only encompasses the belief in the ability of a partner organization to accomplish a task, but also the belief in the goodwill or positive intentions of this partner, and the perception that it adheres to acceptable values (Mayer et al., 1995; Serva, Fuller, and Mayer, 2005). Moreover, as we recognize that individual managers and not organizations as

a whole trust their partners (Dodgson, 1993; Zaheer, McEvily, and Perrone, 1998), we refer to 
interorganizational trust in this article, being "the extent of trust placed in the partner organization by the members of a focal organization" (Zaheer et al., 1998, p. 142).

Although trust and distrust are sometimes viewed as two ends of a continuum, several scholars acknowledge that they are separate, but related constructs (Hardin, 2004; Lewicki, McAllister, and Bies, 1998; Sitkin and Roth, 1993). Following Lewicki et al. (1998, p. 439), we therefore distinguish these concepts from each other, and we define distrust as "confident negative expectations regarding another's conduct" that manifest themselves in fear, vigilance or suspicion (Sitkin and Roth, 1993). Distrust thus derives from the negative hypothetical possibility regarding a partner's behavior and actions (Bachmann, 2001). It arises when partners have an interest in behaving opportunistically (Williamson, 1985). We contend that trust and distrust co-exist, not only because partners can trust each other in one respect and distrust each other regarding other issues (Lewicki et al., 1998), but also because partners may cultivate trust and distrust at the same time so as to reap the benefits from both and to compensate for the weaknesses associated with each of them individually. Trust, for example, always remains a fragile mechanism (Dodgson, 1993), which prompts Langfred (2004, p. 391) to state that "a little skepticism never hurt anyone". This indicates that combinations of trust and distrust may be most beneficial to interorganizational cooperation. To conclude, we thus embrace the idea that trust and distrust coexist (see Miles and Creed, 1995).

Where trust and distrust involve the expectations of managers concerning their partners, formalization involves actual interference in collaborative endeavors. It consists of the codification and enforcement of inputs, outcomes, and interorganizational activities (BijlsmaFrankema and Costa, 2005; Das and Teng, 2001). The principal exponent of formalization in 
interorganizational relationships consists of contractual planning, which refers to the process of "projecting exchanges into the future," and the contracts eventuating from this process (Macneil, 1980 , p. 4). According to transaction cost economists and agency theorists, contracting is primarily aimed at curbing opportunistic behavior and establishing control over partner organizations. It does so by raising the costs of self-interested activities, changing pay-off structures and incentives, and increasing the transparency of relationships and objects of monitoring (Lui and Ngo, 2004; Oxley, 1997; Reuer and Ariño, 2002; Williamson, 1985).

However, formalization does not only fulfill a control function, but also a coordination function, which is gradually receiving more systematic attention in the literature (e.g. Carson, Madhok, and Wu, 2006; Foss and Foss, 2005; Gulati and Singh, 1998; Klein Woolthuis et al., 2005; Madhok, 2002; Mayer and Argyres, 2004). Whereas control problems are primarily rooted in differences in motivation and interest between partners, coordination problems generally arise from the cognitive limitations of individuals. These problems may persist even though partner interests may be aligned (Foss and Foss, 2005; Gulati et al., 2005). From a coordination perspective, contracts may then be interpreted as a means to pursue the alignment of activities and as technical aids to managing relationships (Klein Woolthuis et al., 2005). They help partners to decompose tasks, and to establish and communicate the activities that have to be completed. This is particularly significant for interorganizational relationships in which tasks have to be continuously geared to each other, and in which joint decision making between partners is required (Gulati and Singh, 1998).

As we will argue that trust, distrust, and formal coordination and control affect interorganizational performance and the interpretation that managers give to their partners' 
behaviour, we will also define these constructs here. Interorganizational performance both concerns "the degree of accomplishment of the partners' goals, [...], and the extent to which their pattern of interactions is acceptable to the partners" (Ariño, 2003, p. 23). Support for this stance is provided by De Rond (2003), who found that participants in alliances between pharmaceutical companies and biotechnology firms did not only assess the performance of their relationships on economic or strategic outcomes, but primarily on factors such as the ease or smoothness of cooperation, the extent to which conflicts prevail, and the partners' satisfaction with coordination and communication processes (see also Luo, 2002; Poppo and Zenger, 2002). When we discuss interorganizational performance, we therefore consider the outcomes achieved in a relationship, as well as the relational quality underlying these outcomes (Ariño, 2003; Ariño, De la Torre, and Ring, 2001). Finally, in the context of this paper, interpretation is defined as the meaning that is attributed to a partner's behaviour. Interpretations can then be negative or positive.

Now that we have defined the main constructs in our framework, we elucidate how trust, distrust, and formal coordination and control may evolve in interorganizational relationships. We do so by explaining the research framework depicted in Figure 1. The general thrust of our argument is that managers' expectations during initial stages of cooperation - in terms of the levels of trust and distrust that they hold towards their partners - have a major impact on the development of these relationships in later stages (see also Doz, 1996; Ferrin et al., 2005; Klein Woolthuis et al., 2005). This stems from their influence on formal coordination and control, interorganizational performance, and the favorability with which managers interpret the behavior of their partners. These effects increase the likelihood that existing expectations are reinforced and that trust and distrust develop along vicious or virtuous cycles. 
Insert Figure 1 around here

\section{TRUST AND DISTRUST AFFECTING FORMAL COORDINATION AND CONTROL}

A large body of literature proposes that trust may act as a substitute for formal control, as higher degrees of trust reduce the need for control (e.g. Das and Teng, 2001; Dyer and Singh, 1998; Gulati, 1995; Inkpen and Currall, 2004; Zaheer and Venkatraman, 1995). From this perspective, trust and formal control consist of "functionally equivalent strategies for absorbing uncertainty and dealing with the freedom and indeterminacy of other agents" (Knights et al., 2001, p. 329; see also Reed, 2001; Zucker, 1986). Both forms governance increase the perceived predictability of social actors' future behaviors (Luhmann, 1979; Nooteboom, 2002). This implies that if managers lose trust in their partner, more resources have to be invested in formal control (Dyer and Chu, 2003; Inkpen and Currall, 2004), while increments in trust reduce the need to do so (Inkpen and Currall, 2004; Zaheer et al., 1998). This substitution effect between trust and formal control is conditional upon the existence of a certain degree of distrust. After all, if managers do not have any reason to distrust their partner (e.g. the perceived opportunities and payoffs for opportunistic behavior by a partner are low), a lack of trust does not have to be compensated by a an increase in formal control. This leads us to our first proposition (see also Figure 1).

Proposition 1a: In the presence of distrust, increases in trust reduce the need for formal control, while decreases in trust augment the need for formal control. 
Trust also exhibits a positive relationship with formalization, in that higher degrees of trust enable higher levels of formal coordination and control (Dekker, 2004). Trust facilitates open communication and negotiations on the details of contracts, "including the thorny sensitive clauses like relationship termination" (Klein Woolthuis et al., 2005, p. 831). Furthermore, by facilitating information sharing (Dyer and Chu, 2003; Dyer and Singh, 1998) and by functioning as a "lubricant of economic exchange" (Knights et al., 2001, p. 312), trust enables parties to record aspects of their relationships in formal contracts and documents. Distrust, instead, entails low degrees of information exchange, and limited opportunities to observe and learn from partners (Maguire et al., 2001), which reduce their possibilities to formalize the relationship. We contend that the enabling character of trust and the restricting nature of distrust pertain both to formalization's coordination function and its control function. After all, communication and information exchange are conducive to codification and enforcement in general. Moreover, as the coordination and control functions of formalization are strongly intertwined, an enabling or restricting influence on one of them will generally affect the other function as well (Foss and Foss, 2005; Madhok, 2002). This leads us to the following proposition (see also Figure 1).

Proposition 1b: Decreasing levels of distrust and increasing levels of trust augment the ability of managers to establish formal means of coordination and control.

\section{PERFORMANCE EFFECTS}

In this paragraph, we discuss the performance effects of trust, distrust, and formal coordination and control that feature most prominently in the literature. 


\section{Basic levels of trust and excessive levels of distrust}

Basic levels of trust function as a prerequisite for interorganizational cooperation, because they help to generate and maintain interaction and social order (Bachmann et al., 2001; Inkpen and Curall, 2004; Luhmann, 1979; Reed, 2001). In particular, "[I]n the face of unknown conditions, unintended consequences, existing zones of uncertainty, and the prevailing dialectic of control, social interaction always requires some trust" (Sydow and Windeler, 2003, p. 79). Otherwise, interorganizational relationships would be pervaded by very high levels of uncertainty, causing managers to continually question the motives and competences of their partners (Das and Teng, 2001; McEvily et al., 2003a). In such cases, they become less willing to take risks, and they

refrain from sharing perspectives and knowledge (Bijlsma-Frankema, 2004; March and Olsen, 1975). Similarly, we contend that excessively high levels of distrust prohibit beneficial cooperation as well, as potential partners may become reluctant to initiate relationships, or because their relationships are pervaded by so much suspicion, that they are not able to capitalize on joint opportunities for value creation. We capture this in proposition 2 (see also Figure 1).

Proposition 2: Very low levels of trust and very high levels of distrust have a negative effect on interorganizational performance.

\section{Basic and excessive levels of formal coordination and control}

Analogue to trust, basic levels of formal coordination and control form a precondition for people to engage in transactions with external partners as well (Bachmann, 2001; Dasgupta, 1988; Johnson, McMillan, and Woodruff, 2002; Malhotra and Murnighan, 2002). Irrespective of the level of trust, certain levels of coordination and control are necessary to endow participants in interorganizational relationships with a certain degree of certainty, stability, and guidance 
(Langfred, 2004; Weick, 2001), without which chaos is likely to reign (Luo, 2002; Mintzberg, 1994; Volberda, 1998). In this respect, Dyer and Chu (2003, p. 64) notice that "it seems that even for high-trusting relationships, it is necessary to spend some effort up-front to make sure that the responsibilities of each party are clearly spelled out". Support is also provided by Hoecht's (2004) study of collaborative research projects, in which he found that legal instruments such as detailed contracts were considered normal rules of the game, which were not even relaxed if parties had long cooperative histories.

Very high levels of formal coordination and control can be detrimental to interorganizational performance as well, because they may entail "cumbersome, overregulated, and impersonal processes that individuals are forced to adhere to" (Beck and Kieser, 2003, p. 794). Excessive formalization leads to conflict and disagreement among parties (Ring and Van de Ven, 1994). It also has a retarding effect on creativity and innovation, and it inhibits the flexibility that is needed for coping with complex, ambiguous and unstable task environments (Mintzberg, 1994; Nooteboom, 1999; Volberda, 1998). High levels of formalization may further stifle desirable mutual accommodations (Ireland et al., 2002; Nooteboom, 1999), and easily degenerate into formalism (Balogun and Johnson, 2004; Mintzberg, 1994; Starbuck, 1983). Finally, they may result in areas of unilateral dependence (Lusch and Brown, 1996; Macneil, 1980), hold-up problems (Klein, Crawford, and Alchian, 1978), and considerable transaction costs (Williamson, 1985). We therefore contend that, all else remaining equal, very low and very high levels of formal coordination and control have a negative effect on interorganizational performance. We capture this in a third proposition (see also Figure 1). 
Proposition 3: Very low and very high levels of formal coordination and control have a negative effect on interorganizational performance.

\section{Combinations of governance forms}

Hitherto, we have described several individual effects of trust, distrust, and formal coordination and control on interorganizational performance. However, we also advance that combinations of these governance forms may affect interorganizational performance. As we cannot discuss all of them in this article, we focus on one particularly dangerous combination here, consisting of a high level of trust joined with low levels of distrust and formal control. In this situation, the danger lurks around the corner that a firm becomes an easy target for exploitation by greedy partners (Wicks et al., 1999; Zeng and Chen, 2003). This arises from the fact that trust may be based on systematic biases (Jeffries and Reed, 2000; McEvily, Perrone, and Zaheer, 2003b), and from the notion that firms can never completely rule out that partners see it as advantageous to cheat (Lane and Bachmann, 1997). It is reinforced by the fact that even trustworthy partners can be relied upon to be untrustworthy if the incentives are large enough (Dasgupta, 1988). Anderson and Jap (2005, p. 78) therefore advance that "while cozy relationships sound good in theory, such relationships also provide an opportunity for covert activities designed to systematically cheat a partner". Similarly, Langfred (2004) argues that, under certain conditions, trust can be harmful, as it encourages actors to suspend judgment of others. This could manifest itself in the initial denial of problems, in giving others the benefit of the doubt, and in giving second chances more frequently (Hoetker, 2005). Managers asking themselves "Our partners are so trustworthy; how could they be exploiting us?" may be reminiscent of such cases (Anderson and Jap, 2005, p. 76). 
In fact, trust may go so far that "one takes the relation for granted and does not continuously think about opportunities to gain extra advantage from it, nor does one consider the other to do so" (Klein Woolthuis et al., 2005, p. 816). An example consists of a relationship between an automaker and one of its suppliers as described by Anderson and Jap (2005). The automaker invested heavily in this relationship, which eventuated in a high level of mutual trust. However, the automaker's trust was abused by the supplier, which "cut corners in a calculating manner" (Anderson and Jap, 2005, p. 77). Such examples show that trust sometimes "binds and blinds, making economic actors insufficiently vigilant and excessively vulnerable" (McEvily et al., 2003b, p. 98), and that trust can lead to naiveté and a take-it-for-granted mind-set in which relationships are put on cruise control (Anderson and Jap, 2005; Carson et al., 2006). If trust is not accompanied by certain degrees of healthy suspicion or formal controls, an organization thus risks being cheated, or missing out on major opportunities. We capture this in a fourth proposition (see also Figure 1).

Proposition 4: Relationships in which high levels of trust are accompanied by low levels of distrust and/or formal control entail higher performance risks than relationships in which high levels of trust are accompanied by higher levels of distrust and/or formal control.

\section{CHANGES IN TRUST, DISTRUST, AND FORMAL COORDINATION AND CONTROL}

As the framework in Figure 1 shows, interorganizational governance is not a static phenomenon. During the relationship, managers may update their expectations and wish to bring about changes in the formal coordination and control mechanisms that they adopt (Bijlsma-Frankema and Costa, 2005; Wicks et al., 1999). Such changes become more likely when interorganizational 
performance - in terms of the relational quality experienced and the outcomes achieved - is considered weak, or worse than expected in early stages of cooperation.

\section{Expectancy disconfirmation}

When interorganizational performance is relatively weak, managers may come to perceive their partners as being less trustworthy than they originally thought them to be. This assertion derives from work on expectancy disconfirmation theory, which concurs that managers' perceptions of performance trigger a comparison of actual behavior and outcomes against their expectations (Oliver, Balakrishnan, and Barry, 1994). When positive disconfirmation prevails, trust in a partner is reinvigorated. In case of negative disconfirmation, managers may blame their partners for the discrepancy between the actual and expected performance. Accordingly, they may perceive that their partner is less trustworthy (March and Olsen, 1975). In a similar vein, negative disconfirmation may cause managers to experience a relatively high propensity to act, in order to reduce deviations between the actual performance of the relationship and their expectations. This urge to act, or feeling that something has to be done, may translate itself into a heightened level of formal coordination and control (Sitkin and Bies, 1993). Accordingly, we propose that levels of interorganizational performance achieved in early stages of cooperation affect the development of trust and formal coordination and control in subsequent stages through the (dis)confirmation of expectations (see also Figure 1).

Proposition 5: The lower interorganizational performance is in early stages of cooperation, the larger the decline in trust in subsequent stages of development. 
Proposition 6: The lower interorganizational performance is in early stages of cooperation, the more managers perceive a need to increase formal coordination and control.

\section{Interpreting the behavior of partners}

Changes in trust and distrust also stem from the interpretation that managers attribute to the behavior of their partners. These interpretations, in turn, depend on the performance that has been achieved in relationships during earlier stages of cooperation, the degrees of formal coordination and control that have been adopted, and the expectations of managers concerning their partners. Concerning performance, we believe that managers become more inclined to interpret the behavior of their partners negatively when the quality of a relationship is low or when the outcomes of a relationship are unfavorable. In contrast, when performance levels are high, there is no need to blame the partner, and its behavior is therefore likely to be interpreted in a more favorable way. This is captured in the following proposition (see also Figure 1).

Proposition 7: The higher the level of interorganizational performance in prior stages of cooperation, the more positive are managers' interpretations of the behavior of their partner.

Considering formal coordination and control, we propose that higher levels of formalization make it easier for managers to interpret the behavior of their partners. Formalization assists them in creating shared expectations and it helps them to define and agree on the coordination and control of activities and outcomes (Mayer and Argyres, 2004). In contrast, when formalization is low, much room is left for widely different perceptions and frames against which meaning is made. Such a situation occurred, for example, in an alliance between Ciba Geigy and Alza, where the absence of reasonably detailed contractual agreements led to "growing suspicions and 
tensions as each partner was searching for clues in the behavior of the other" (Doz, 1996, p. 68). In these and similar cases, it becomes much harder for managers to interpret the behavior of their partner. The clarity of definitions and expectations that results from formalization thus facilitates assessments by managers of their partners' behavior (Carson et al., 2006; Malhotra and Murnighan, 2002). This leads us to the following proposition (see also Figure 1).

Proposition 8: The higher the level of formalization, the easier it becomes for managers to interpret the behavior of their partners in subsequent stages of development.

Finally, as managers make sense in ways that minimize the discrepancies between their expectations and their observations (Kahneman and Tversky, 1973), the behavior of partners is generally interpreted so that it reinforces existing preconceptions of trust and distrust (March and Olsen, 1975; Weick, 1995). Consequently, initial levels of trust and distrust strongly influence whether behavior by a partner results in spirals of distrust, defensive behavior, conflict, and increased emphasis on monitoring and control (Ghoshal and Moran, 1996), or in increased levels of commitment and trust in a partner (Klein Woolthuis et al., 2005). High levels of distrust, for example, lead managers to interpret their partner's behavior in a less favorable light than would be the case if high trust would prevail (Kramer, 1994). When managers distrust their partners, they hesitate to reveal information, reject influence, and evade control, which complicates trust building and reinforces distrust, potentially causing partners to fall into spirals of suspicion (Anderson and Jap, 2005; Zand, 1972). Acts by partners that are intended to restore trust may even increase suspicion and alienate partners further from each other (Avadikyan et al., 2001; Hoecht, 2004; Liebeskind and Oliver, 1998; Sitkin and Stickel, 1996). They may be perceived as evidence that a firm's goodwill or competence is thrown into doubt, rendering them signals of 
distrust (Costa, 2003; Das and Teng, 1998, 2001; Ghoshal and Moran, 1996; Jap and Ganesan, 2000; Poppo and Zenger, 2002; Sitkin and Roth, 1993). Formalization does not contribute to coordination or control here, but it becomes destructive, undermining the development of trust (e.g. Lewicki et al., 1998; Sitkin and Roth, 1993). It discourages partner contributions to a relationship, provokes human fights and aversions to change (Bijlsma-Frankema, 2004), and gives rise to a low trust atmosphere, which is frequently reciprocated with even more formal constraints, possibly eventuating in "inflationary spirals" of increasingly formalized relationships (Sitkin and Roth, 1993, p. 367), and in relationships that are locked-up in formalities (Nooteboom, 1999; Parkhe, 1993). Van Marrewijk (2004) offers an example of such a spiral in his description of Unisource, an alliance of Swedish Telia, Dutch KPN Telecom, Swiss Telecom, and Spanish Telefónica. He clarifies that as trust did not develop, the partners turned to more formal control mechanisms. This slowed down decision-making processes and diminished the competitiveness of the alliance, so that trust and commitment deteriorated even more.

Conversely, when participants in interorganizational relationships initially experience high levels of trust, attempts by their partner to establish higher levels of formal coordination and control may be regarded as symbols of the sharing of values and the articulation of communal norms and customs (Zucker, 1986). Participants then presume that the other party is acting in good faith and they will interpret partner behavior more positively (Adobor, 2005; Uzzi, 1997). In these situations, a partner's willingness to formalize becomes a signal of commitment (Klein Woolthuis et al., 2005), indicating that it cares about the relationship and that it intends to put efforts into achieving the objectives that were set (Serva et al., 2005). Higher levels of trust ensue, which enable partners to capture other aspects of the relationship in formal documents again (Mayer and Argyres, 2004; Poppo and Zenger, 2002). We capture this in a final set of propositions. 
Proposition 9: The higher the level of distrust and the lower the level of trust that managers have in their partners, the more negative is their interpretation of the behavior of their partner.

Proposition 10: The more positive managers' interpretations of the behavior of their partners are, the lower is the level of distrust and the higher the level of trust during subsequent stages of cooperation.

Collectively our framework supports Doz's (1996, p. 77) idea that initial conditions characterizing interorganizational cooperation have "disproportionate" effects on the development of interorganizational relationships. Low levels of trust and high levels of distrust in early stages of cooperation, for example, entail a high need for formal control, and a low ability to install formal means of coordination and control (P1). The resulting combination of trust, distrust, and formalization has a negative impact on interorganizational performance ( $\mathrm{P} 2, \mathrm{P} 3$, and P4), which subsequently diminishes trust and increases distrust (P5). In addition, low levels of interorganizational performance lead to an increase in formal coordination and control (P6), and they entail negative interpretations of partner behavior (P7). As these interpretations are also shaped by the degrees of formal coordination and control (P8), and by initial degrees of trust and distrust (P9), trust is likely to diminish even more, whereas distrust tends to increase further (P10). The framework thus shows that starting conditions - in the form of trust and distrust - may trigger vicious and virtuous cycles of development (Adobor, 2005; Gambetta, 1988; Macaulay, 1963; McEvily et al., 2003b). This observation is congruent with Zand's (1972) spiral reinforcement model and with findings from Anderson and Jap (2005), indicating that a significant portion of the more than 200 industrial partnerships that they studied exhibited the formation of dysfunctional spirals of distrust. 


\section{DISCUSSION}

In this article, we have developed a conceptual framework on the evolution of trust, distrust, and formalization in interorganizational relationships. Building on the work of other researchers (Doz, 1996; Ferrin et al., 2005; Klein Woolthuis et al., 2005), we argued that starting conditions consisting of initial levels of trust and distrust - leave strong imprints on the development of cooperative relationships. Starting conditions do not only influence the degrees of formal coordination and control and the levels of performance achieved in early stages of cooperation, but they also affect how managers interpret the behavior of their partners. As a result, trust, distrust, and formalization tend to develop along self-reinforcing paths. Our assertions were captured in an integrative conceptual framework, which reconciles hitherto fragmented views on the evolution of trust, distrust, and formalization in interorganizational relationships.

\section{Theoretical and practical implications}

The model and arguments advanced in this article have significant implications for both research and practice. They show how apparently inconsistent arguments and empirical evidence on the trust-control nexus can be reconciled, and they describe how governance forms may evolve in interorganizational relationships. More specifically, they suggests that mono-causal explanations for observations on governance forms provide incomplete accounts of reality (see also Bachmann, 1998; Möllering, 2005), and that an integrative approach to theory development has to be taken to fully understand their evolution in interorganizational relationships. Moreover, our arguments indicate that neither trust nor formalization should become ends in themselves, as this

could lead to naiveté or rigidity respectively. Inquiries into interorganizational governance should therefore be accompanied by performance assessments, so trust and formal coordination and control do not become final aims (see also Suen, 2005). Furthermore, the model indicates that 
managers have to seriously consider refraining from interorganizational cooperation when starting conditions are unfavorable, and breaking off relationships that are characterized by negative self-reinforcement in early stages of cooperation. Although this may seem obvious, we emphasize it here, because many relationships persist although prospects are bad (Inkpen and Ross, 2001). We suggest that this may partly derive from managers being unaware of the significance of starting conditions and self-reinforcing effects.

\section{Future research}

Several avenues for further research can be identified. A first and promising research direction could be to investigate the extent to which the relationships in our framework are contingent upon the nature of economic exchanges and the legal regimes in which cooperation takes place. These factors may explain a relatively large share of the variance in trust and control (BijlsmaFrankema and Costa, 2005). Sitkin and Stickel (1996), for example, have indicated that the degree of formalization should match the nature of the task performed to prevent escalating cycles of trust deterioration from developing. Williamson (1985) adds that relationships that are embedded in uncertain environments and for which parties have to make investments in relationspecific assets demand more formal control than relationships for which these investments are not required. Others have argued that formal control is problematic in exploration contexts (Oxley, 1997), as the scope of relationships cannot be clearly defined in advance, behaviors cannot be observed, and performance tends to be ambiguous (Carson et al., 2006; Das and Teng, 2001; Dirks, 2000; Hoecht, 2004; Sitkin and Roth, 1993; Sitkin and Stickel, 1996; Wicks et al., 1999). Although the trust-based mode of governance is probably risky here (Carson et al., 2006), it may be the only option for leveraging the resources that are critical to competitive advantage (BijlsmaFrankema, 2004; Bijlsma-Frankema and Koopman, 2004; McEvily et al., 2003b). 
In a similar vein, different institutional environments give rise to distinct relationships between trust and formalization (Deakin and Wilkinson, 1998; Rus and Iglič, 2005). Contractual agreements in the UK, for example, are frequently the result of exhaustive negotiations in which each party attempts to impose conditions upon the other. Contracts then easily become a signal of low trust. In Germany, instead, contracts are used to reassure partners of the common, or shared legal principles to which they wish to adhere, something which fosters trust (Bachmann, 2001). These examples indicate that the relationships that we have depicted in our framework are contingent upon the nature of economic exchanges and on the legal regimes in which these take place, something which clearly deserves more attention in future research (Bijlsma-Frankema and Costa, 2005).

A second option for future research concerns the ambiguity that surrounds the intentions that partners have and their ability to communicate these intentions (see also Carson et al., 2006; Klein Woolthuis et al., 2005; Serva et al., 2005). This is important, as interpretation processes can be fraught with missteps and errors as well as systematic biases (March and Olsen, 1975), so that the development of trust is affected by the ability of trading partners to "read each other," and on their ability to "signal trustworthiness" (Carson et al., 2003). Third, and in line with research by Ferrin et al. (2005) and Serva et al. (2005), our framework may be refined by distinguishing the actions and reactions from one party from those of another party. This would offer a better reflection of the reciprocal nature of trust-building between partners. Fourth, more attention could be paid to the negative consequences or dysfunctions of trust, and the positive aspects or functions of formalization, so as to develop a more balanced perspective on these governance forms. The positive sentiments surrounding most research on trust (Dirks and Ferrin, 2001) and the negative connotation that many people have regarding formalization (Beck and Kieser, 2003) 
may be replaced by images of both concepts that are closer to reality. Finally, research efforts could focus on the interventions that managers undertake to make sure that trust and formalization do not degrade or escalate beyond certain levels. Insights into the ways in which self-reinforcing cycles can be broken, and how trust can be repaired could further advance our understanding of the evolution of trust and formalization in interorganizational relationships.

Concluding, we have developed a conceptual framework, which shows that trust and distrust during initial stages of cooperation leave strong imprints on the development of collaborative relationships in later stages of development. This stems from their impact on formal coordination and control, interorganizational performance, and the interpretations that managers attribute to the behavior of their partners. Our framework reconciles hitherto fragmented views on the evolution of trust, distrust, and formal coordination and control in collaborative relationships, thereby offering a fertile basis for further theorizing in this field.

ACKNOWLEDGEMENTS: This research has benefited from inspiring discussions with Africa Ariño, Justin Jansen, and Rosalinde Klein Woolthuis. We also thank all participants of the third EIASM Workshop on Trust Within and Between Organizations, held on the $23^{\text {rd }}$ and $24^{\text {th }}$ of October 2003 in Amsterdam, for their helpful comments and suggestions, and we are grateful for the comments issued by several attendees of the $65^{\text {th }}$ Academy of Management Conference. The research has further profited from financial support of the RSM Erasmus University Trust Fund and Erasmus Research Institute of Management. A special word of thanks is directed at the editors and reviewers of this special issue, whose comments have led to significant improvements of the manuscript. All remaining errors are the responsibility of the authors. 


\section{REFERENCES}

Adobor, H. (2005). Trust as sensemaking: The microdynamics of trust in interfirm alliances. Journal of Business Research, 58, 330-337.

Anderson, E., \& Jap, S.D. (2005). The dark side of close relationships. MIT Sloan Management Review, 46, 75-82.

Ariño, A. (2003), Measures of collaborative venture performance: An analysis of construct validity. Journal of International Business Studies, 34, 66-79.

Ariño, A., De la Torre, J. \& Ring, P.S. (2001). Relational quality: Managing trust in corporate alliances. California Management Review, 44(1), 109-131.

Avadikyan, A., Llerena, P., Matt, M., Rozan, A. \& Wolff, S. (2001). Organizational rules, codification and knowledge creation in inter-organisation cooperative agreements. Research Policy, 30, 1443-1458.

Bachmann, R. (1998). Conclusion: Trust - conceptual aspects of a complex phenomenon. In C. Lane and R. Bachmann (Eds.), Trust within and between organisations, 298-322. Oxford: Oxford University Press.

Bachmann, R. (2001). Trust, power and control in trans-organizational relations. Organization Studies, 22(2), 337-365.

Bachmann, R., Knights, D., \& Sydow, J. (2001). Trust and control in organizational relations. Organization Studies, 22(2), v-viii.

Bachmann, R. (2004). The coordination of relations across organizational boundaries. International Studies of Management \& Organization, 33(2), 7-21.

Balogun, J., \& Johnson, G. (2004). Organizational restructuring and middle manager sensemaking. Academy of Management Journal, 47(4), 523-549.

Beck, N., \& Kieser, A. (2003). The complexity of rule systems, experience, and organizational learning. Organization Studies, 24(5), 793-814.

Bijlsma-Frankema, K. (2004). Dilemmas of managerial control in post-acquisition processes. Journal of Managerial Psychology, 19(3), 252-268.

Bijlsma-Frankema, K., \& Costa, A.C. (2005). Understanding the trust-control nexus. International Sociology, 20(3), 259-282.

Bijlsma-Frankema, K., \& Koopman, P. (2004). The oxymoron of control in an era of globalisation. Journal of Managerial Psychology, 19(3), 204-217. 
Carson, S.J., Madhok, A., Varman, R., \& John, G. (2003). Information processing moderators of the effectiveness of trust-based governance in interfirm R\&D collaboration. Organization Science, 14(1), 45-56.

Carson, S.J., Madhok, A., \& Wu, T. (2006). Uncertainty, opportunism and governance: The effects of volatility and ambiguity on formal and relational contracting. Forthcoming in Academy of Management Journal.

Costa, A.C. (2003). Work team trust and effectiveness. Personnel Review, 32(5), 605-623.

Das, T.K., \& Teng, B.-S. (1998). Between trust and control: Developing confidence in partner cooperation in alliances. Academy of Management Review, 23, 491-512.

Das, T.K., \& Teng, B.-S. (2001). Trust, control, and risk in strategic alliances: An integrated framework. Organization Studies, 22(2), 251-283.

Dasgupta, P. (1988). Trust as a commodity. In D. Gambetta (Ed.), Trust: Making and breaking cooperative relationships, 49-72. New York: Blackwell.

Deakin, S., \& Wilkinson, F. (1998). Contract law and the economics of interorganizational trust. In C. Lane and R. Bachmann (Eds.), Trust within and between organisations, 146-172. Oxford: Oxford University Press.

Dekker, H.C. (2004). Control of inter-organizational relationships: Evidence on appropriation concerns and coordination requirements. Accounting, Organizations, and Society, 29, 27-49.

De Rond, M. (2003). Strategic alliances as social facts. Cambridge: Cambridge University Press.

De Wever, S., Martens, R., \& Vandenbempt, K. (2005). The impact of trust on strategic resources acquisition through interorganizational networks: Towards a conceptual model. Human Relations, 58, 1523-1543.

Dirks, K.T. (2000). Trust in leadership and team performance: Evidence from NCAA basketball. Journal of Applied Psychology, 85, 1004-1012.

Dirks, K.T., \& Ferrin, D.L. (2001). The role of trust in organizational settings. Organization Science, 12, 450-467.

Dodgson, M. (1993). Learning, trust, and technological collaboration. Human Relations, 16(1), 77-95.

Doz, Y.L. (1996). The evolution of cooperation in strategic alliances: Initial conditions or learning processes? Strategic Management Journal, 17, 55-83.

Dyer, J.H., \& Singh, H. (1998). The relational view: Cooperative strategies and sources of interorganizational competitive advantages. Academy of Management Review, 23(4), 660-679. 
Dyer, J., \& Chu, W. (2003). The role of trustworthiness in reducing transaction costs and improving performance: Empirical evidence from the United States, Japan, and Korea. Organization Science, 14(1), 57-68.

Ferrin, D.L., Bligh, M.C. \& Kohles, J.C. (2005). It takes two to tango: An interdependence analysis of trust and cooperation spirals in interpersonal and intergroup relationships. Working paper presented at the 2005 annual meeting of the Academy of Management.

Foss, K., \& Foss, N.J. (2005). Resources and transaction costs: how property rights economics furthers the resource-based view. Strategic Management Journal, 26, 541-553.

Gambetta, D. (1988). Can we trust trust? In D. Gambetta (Ed.), Trust: Making and breaking cooperative relationships, 213-237. New York: Blackwell.

García-Canal, E. Valdés-Llaneza, A., \& Ariño, A. (2003). Effectiveness of dyadic and multiparty joint ventures. Organization Studies, 24(5), 743-770.

Ghoshal, S., \& Moran, P. (1996). Bad for practice: A critique of the transaction cost theory. Academy of Management Review, 21, 13-47.

Gulati, R. (1995). Does familiarity breed trust? The implications of repeated ties for contractual choice in alliances. Academy of Management Journal, 38, 85-112.

Gulati, R., P.R. Lawrence, \& P. Puranam (2005). Adaptation in vertical relationships: Beyond incentive conflict. Strategic Management Journal, 26, 415-440.

Gulati, R., \& Singh, H. (1998). The architecture of cooperation: Managing coordination costs and appropriation concerns in strategic alliances. Administrative Science Quarterly, 43, 781-814.

Hardin, R. (2004). Distrust. New York: Russell Sage Foundation.

Hoecht, A. (2004). Control in collaborative research and technology development: A case study in the chemical industry. Journal of Managerial Psychology, 19(3), 218-234.

Hoetker, G. (2005). How much you know versus how well I know you: Selecting a supplier for a technically innovative component. Strategic Management Journal, 26, 75-96.

Inkpen, A.C., \& Currall, S. (2004). The coevolution of trust, control, and learning in joint ventures. Organization Science, 15(5), 586-599.

Inkpen, A.C., \& Ross, J. (2001). Why do some strategic alliances persist beyond their useful life? California Management Review, 44(1), 132-148

Ireland, D., Hitt, M., \& Vaidyanath, D. (2002). Alliance management as a source of competitive advantage. Journal of Management, 28(3), 413-446. 
Jap, S.D., \& Ganesan, S. (2000). Control mechanisms and the relationship life cycle: Implications for safeguarding specific investments and developing commitment. Journal of Marketing Research, 37, 227-245.

Jeffries, F.L., \& Reed, R. (2000). Trust and adaptation in relational contracting. Academy of Management Review, 25(4), 873-882.

Johnson, S., McMillan, J. \& Woodruff, C. (2002). Courts and relational contracts. Journal of Law, Economics and Organization, 18, 221-227.

Kahneman, D., \& Tversky, A. (1973). On the psychology of prediction. Psychological Review, $80,237-251$.

Kale, P., Dyer, J. \& Singh, H. (2002). Alliance capability, stock market response, and long-term alliance success: The role of the alliance function. Strategic Management Journal, 23, 747-767.

Kern, H. (1998). Lack of trust, surfeit of trust: Some causes of the innovation crisis in Gernam industry. In C. Lane and R. Bachmann (Eds.), Trust within and between organisations, 203-213. Oxford: Oxford University Press.

Klein, B., Crawford, R., \& Alchian, A. (1978). Vertical integration appropriable rents, and the competitive contracting process. Journal of Law and Economics, 21(2), 297-326.

Klein Woolthuis, R., Hillebrand, B. \& Nooteboom, B. (2005). Trust, contract and relationship development. Organization Studies, 26, 813-840.

Knights, D., Noble, F., Vurdubakis, T., \& Willmott, H. (2001). Chasing shadows: Control, virtuality and the production of trust. Organization Studies, 22(2), 311-336.

Kramer, R. (1994). The sinister attribution error: Paranoid cognition and collective distrust in organizations. Motivation and emotion, 18, 199-230.

Lane, C., \& Bachmann, R. (1997). Cooperation in inter-firm relations in Britain and Germany: The role of social institutions. British Journal of Sociology, 48(2), 226-254.

Langfred, C.W. (2004). Too much of a good thing? Negative effects of high trust and individual autonomy in self-managing teams. Academy of Management Journal, 47(3), 385-399.

Lewicki, R., McAllister, D., \& Bies, R. (1998). Trust and distrust: New relationships and realities. Academy of Management Review, 23, 438-512.

Liebeskind, J., \& Oliver, A. (1998). From handshake to contract: Intellectual property, trust and the social structure of academic research. In C. Lane, \& R. Bachmann (Eds.), Trust within and between organisations, 118-145. Oxford: Oxford University Press.

Luhmann, N. (1979). Trust and Power. Chichester: Wiley. 
Luhmann, N. (1988). Familiarity, confidence, trust: Problems and alternatives. In D. Gambetta (Ed.), Trust: Making and breaking cooperative relationships, 94-126. New York: Blackwell.

Luo, Y. (2002). Contract, cooperation and performance in international joint ventures. Strategic Management Journal, 23, 903-919.

Lusch, R., \& Brown, J. (1996). Interdependency, contracting, and relational behavior in marketing channels. Journal of Marketing, 60, 19-38.

Macaulay, S. (1963). Non-contractual relations in business: A preliminary study. American Sociological Review, 28, 55-67.

Macneil, I. (1980). The new social contract: An inquiry into modern contractual relations. London: Yale University Press.

Madhok, A. (2002). Reassessing the fundamentals and beyond: Ronald Coase, the transaction cost and resource-based theories of the firm and the institutional structure of production. Strategic Management Journal, 23, 535-550.

Maguire, S., Philips, N., \& Hardy, C. (2001). When 'silence=death', keep talking: Trust, control and the discursive construction of identity in the Canadian HIV/AIDS treatment domain. Organization Studies, 22(2), 285-310.

Malhotra, D., \& Murnighan, J. (2002). The effects of contracts on interpersonal trust. Administrative Science Quarterly, 47(3), 534-559.

March, J., \& Olsen, J. (1975). The uncertainty of the past: Organizational learning under ambiguity. European Journal of Political Research, 3, 149-171.

Mayer, K.J., \& Argyres, N. (2004). Learning to contract: Evidence from the personal computer industry. Organization Science, 15(4), 394-410.

Mayer, R., Davis, J., \& Schoorman, F. (1995). An integrative model of organizational trust. Academy of Management Review, 20, 709-734.

McEvily, B., Perrone, V., \& Zaheer, A. (2003a). Introduction to the special issue on trust in an organizational context. Organization Science, 14(1), 1-4.

McEvily, B., Perrone, V., \& Zaheer, A. (2003b). Trust as an organizing principle. Organization Science, 14(1), 91-103.

Miles, R.E., \& Creed, W.E.D. (1995). Organizational forms and managerial philosophies: A descriptive and analytic review. Research in Organizational Behavior, 17, 333-372.

Mintzberg, H. (1994). The rise and fall of strategic planning. Hemel Hempstead: Prentice Hall. 
Möllering, G. (2005). The trust-control duality: An integrative perspective on positive expectations of others. International Sociology, 20(3), 283-305.

Nooteboom, B. (1999). Inter-firm alliances: Analysis and design. London: Routledge.

Nooteboom, B. (2002). Trust: Forms, foundations, functions, failures, and figures. Cheltenham: Edward Elgar.

Oliver, R.L., Balakrishnan, P.V., \& Barry, B. (1994). Outcome satisfaction in negotiation: A test of expectancy disconfirmation. Organizational Behavior and Human Decision Processes, 60, 252-275.

Oxley, J. (1997). Appropriability hazards and governance in strategic alliances: A transaction cost approach. Journal of Law Economics and Organization, 13, 387-409.

Parkhe, A. (1993). The structuring of strategic alliances: A game theoretic and transaction cost examination of interfirm cooperation. Academy of Management Journal, 36, 794-829.

Poppo, L., \& Zenger, T. (2002). Do formal contracts and relational governance function as substitutes or complements? Strategic Management Journal, 23, 707-725.

Reed, M.I. (2001). Organization, trust, and control: A realist analysis. Organization Studies, 22(2), 201-228.

Ring, P.S., \& Van de Ven, A.H. (1994). Developmental processes of cooperative interorganizational relationships. Academy of Management Review, 19, 90-118.

Rousseau, D., Sitkin, S., Burt, R., \& Camerer, C. (1998). Not so different after all: A crossdiscipline view of trust. Academy of Management Review, 23, 393-404.

Rus, A., \& Iglič, H. (2005). Trust, governance, and performance: The role of institutional and interpersonal trust in SME development. International Sociology, 20(3), 371-391.

Serva, M.A., Fuller, M.A., \& Mayer, R.C. (2005). The reciprocal nature of trust: A longitudinal study of interacting teams. Journal of Organizational Behavior, 26, 625-648.

Sitkin, S. (1995). On the positive effect of legalization on trust. Research on Negotiation in Organizations, 5, 185-217. Greenwich: JAI Press.

Sitkin, S., \& Bies, R.J. (1993). The legalistic organization: Definitions, dimensions, and dilemmas. Organization Science, 4, 345-351.

Sitkin, S., \& Roth, N. (1993). Explaining the limited effectiveness of legalistic 'remedies' for trust/distrust. Organization Science, 4(3), 367-392.

Sitkin, S. \& Stickel, D. (1996). The road to hell: The dynamics of distrust in an era of quality. In R.M. Kramer, \& T.R. Tyler (Eds.), Trust in Organizations, 166-195. Thousand Oaks: Sage. 
Starbuck, W. (1983) Organizations as action generators. American Sociological Review, 48(1), 91-102.

Suen, W.W. (2005). Non-cooperation: The dark side of strategic alliances. Palgrave: New York.

Sydow, J., \& Windeler, A. (2003). Knowledge, trust, and control. International Studies of Management \& Organization, 33(2), 69-99.

Uzzi, B. (1997). Social structure and interfirm competition in inter-firm networks: The paradox of embeddedness. Administrative Science Quarterly, 42(1), 35-67.

Van Marrewijk, A. (2004). Crisis in the transition of telecom alliance Unisource. Journal of Managerial Psychology, 19(3), 235-251.

Volberda, H.W. (1998). Building the flexible firm. Oxford: Oxford University Press.

Weick, K.E. (1995). Sensemaking in organizations. Thousand Oaks: Sage.

Weick, K.E. (2001). Making sense of the organization. Oxford: Blackwell.

Wicks, A.C., Berman, S.L., \& Jones, T.M. (1999). The structure of optimal trust: Moral and strategic implications. Academy of Management Review, 24(1), 99-116.

Williamson, O.E. (1985). The Economic Institutions of Capitalism. New York: Free Press.

Zaheer, A., McEvily, B., \& Perrone, V. (1998). Does trust matter? Exploring the effects of interorganizational and interpersonal trust on performance. Organization Science, 9(2), 141-159.

Zaheer, A., \& Venkatraman, N. (1995). Relational governance as an interorganizational strategy: An empirical test of the role of trust in economic exchange. Strategic Management Journal, 16, 373-392.

Zand, D.E. (1972). Trust and managerial problem solving. Administrative Science Quarterly, 17(2), 229-239.

Zeng, M., \& Chen, X.-P. (2003). Achieving cooperation in multiparty alliances: A social dilemma approach to partnership management. Academy of Management Review, 28(4), 587-605.

Zucker, L.G. (1986). Production of trust: Institutional sources of economic structure. In B. Staw et al. (Eds.), Research in Organizational Behavior, 8, 53-111. Greenwich: JAI Press. 
FIGURE 1

The evolution of trust, distrust, and formalization in interorganizational relationships

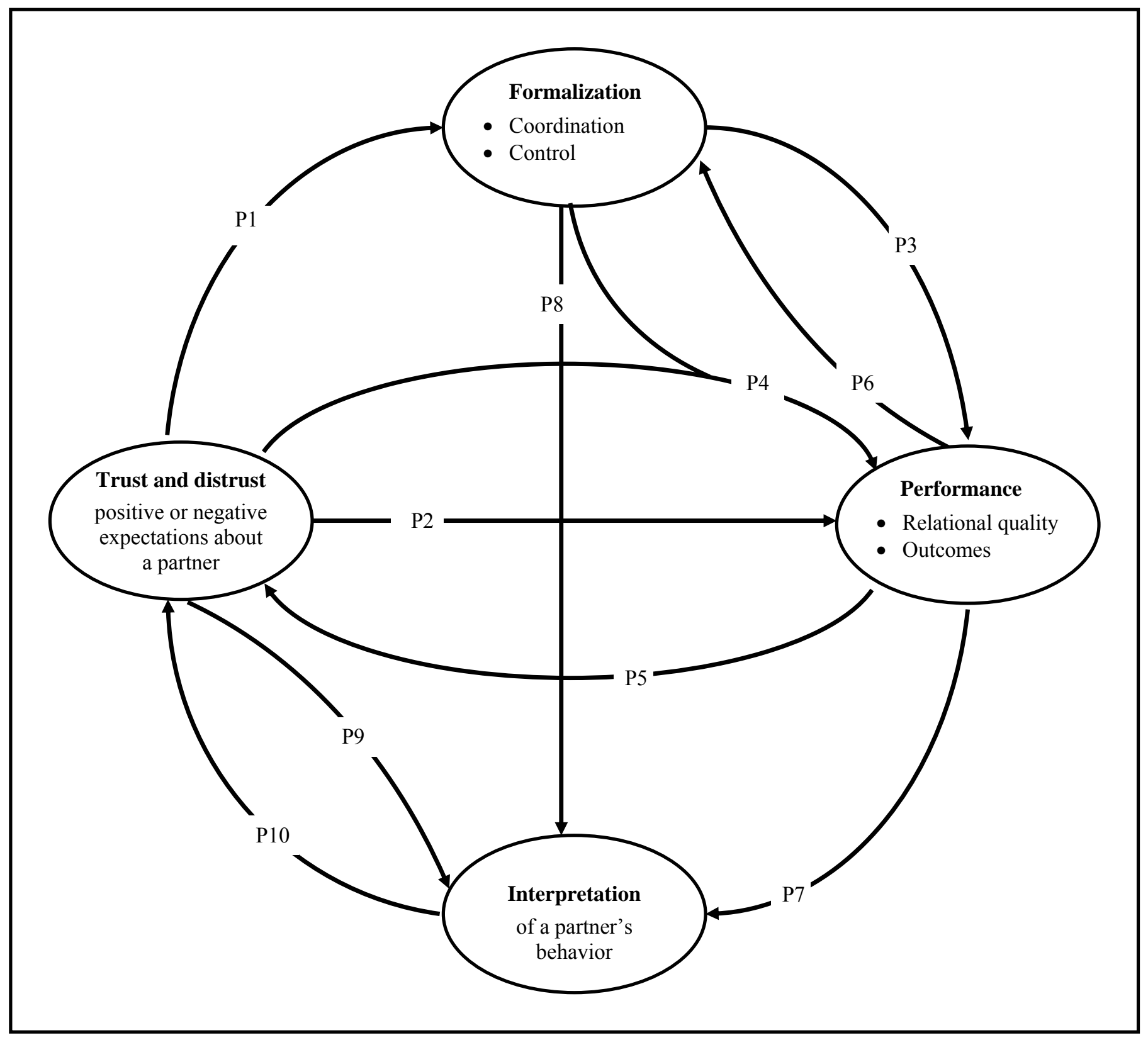




\section{Publications in the Report Series Research ${ }^{*}$ in Management}

\section{ERIM Research Program: "Strategy and Entrepreneurship"}

2006

Modeling Brand Extension as a Real Option: How Expectation, Competition and Financial Constraints Drive the Timing of Extensions

Lenny H. Pattikawa

ERS-2006-030-STR

http://hdl.handle.net/1765/7855

Coping with Problems of Understanding in Interorganizational Relationships: Using Formalization as a Means to make Sense Paul W.L. Vlaar, Frans A.J. Van den Bosch and Henk W. Volberda

ERS-2006-034-STR

On the Evolution of Trust, Distrust, and Formal Coordination and Control in Interorganizational Relationships: Towards an Integrative Framework

Paul W.L. Vlaar, Frans A.J. Van den Bosch and Henk W. Volberda ERS-2006-035-STR

Complex Incremental Product Innovation in Established Service Firms: A Micro Institutional Perspective Patrick A.M. Vermeulen, Frans A.J. Van den Bosch and Henk W. Volberda ERS-2006-037-STR

Exploratory Innovation, Exploitative Innovation, and Performance: Effects of Organizational Antecedents and Environmental Moderators

Justin J.P. Jansen, Frans A.J. Van den Bosch and Henk W. Volberda

ERS-2006-038-STR

\footnotetext{
A complete overview of the ERIM Report Series Research in Management: https://ep.eur.nl/handle/1765/1

ERIM Research Programs:

LIS Business Processes, Logistics and Information Systems

ORG Organizing for Performance

MKT Marketing

F\&A Finance and Accounting

STR Strategy and Entrepreneurship
} 